\title{
Childhood obesity: immune response and nutritional approaches
}

\section{Thea Magrone and Emilio Jirillo*}

Department of Basic Medical Sciences, Neuroscience and Sensory Organs, University of Bari, Bari, Italy

\section{Edited by:}

Johan Garssen, Utrecht University, Netherlands

\section{Reviewed by:}

Edda Fiebiger, Children's Hospital

Boston and Harvard Medical School, USA

Margarida Castell, University of

Barcelona, Spain

\section{*Correspondence:}

Emilio Jirillo, Department of Basic

Medical Sciences, Neuroscience and

Sensory Organs, University of Bari,

Policlinico-Piazza G. Cesare, Bari

11-70124, Italy

e-mail:emilio.jirillo@uniba.it
Childhood obesity is characterized by a low-grade inflammation status depending on the multicellular release of cytokines, adipokines, and reactive oxygen species. In particular, the imbalance between anti-inflammatory $T$ regulatory cells and inflammatory $T$ helper 17 cells seems to sustain such a phlogistic condition. Alterations of gut microbiota since childhood also contribute to the maintenance of inflammation. Therefore, besides preventive measures and caloric restrictions, dietary intake of natural products endowed with antioxidant and anti-inflammatory activities may represent a valid interventional approach for preventing and/or attenuating the pathological consequences of obesity. In this regard, the use of prebiotics, probiotics, polyphenols, polyunsaturated fatty acids, vitamins, and melatonin in human clinical trials will be described.

Keywords: atherosclerosis, children, diabetes, immunity, microbiota, nutrition, obesity, oxidative stress

\section{INTRODUCTION}

Nowadays, childhood obesity has become an epidemic all over the world. In terms of estimates, 200 million school-age children are overweight/obese and 40-50 million of them are obese (1).

According to current literature, $70 \%$ of obese adolescents become obese in adult life also in relation to parental obesity (2-4). Of note, overweight and obesity seem to be irrespective of the socio-economic conditions and income status, as reported by Lobstein et al. (5), Popkin and Gordon-Larsen (6), and Wang and Lobstein (7). However, in developed countries, social inequality represents a risk of developing obesity (8). On the other hand, genetic, epigenetic, environmental factors, and inappropriate life styles (imbalanced diets and sedentary life) greatly contribute to the development of obesity and related diseases, such as insulin resistance, type 2 diabetes, and metabolic syndrome (MetS) (9).

With regard to the etiology of childhood obesity (10), the prenatal period should be considered as a critical period for its development. Excessive or low calorie intake by the mother during

Abbreviations: AGEs, advanced glycation end products; AMP, antimicrobial peptide; BMI, body mass index; DCs, dendritic cells; DHA, docosahexaenoic acid; EGCG, epigallocatechin-3-gallate; EPA, eicosapentaenoic acid; GPCR, G-protein coupled receptor; IFN, interferon; Ig, immunoglobulin; IL, interleukin; LP, lamina propria; LPS, lipopolysaccharides; MCP, monocyte chemotactic protein; MedDiet, Mediterranean diet; MetS, metabolic syndrome; n-3 PUFAs, omega-3 polyunsaturated fatty acids; n-6 PUFAs, omega-6 polyunsaturated fatty acids; NADPH, nicotinamide adenine dinucleotide phosphate; NASH, non-alcoholic steatohepatitis; NK, natural killer; NO, nitric oxide; PA, physical activity; PAI, plasminogen activator inhibitor; PKC, protein kinase C; PP, Peyer's patches; PSA, polysaccharide A; RAGEs, advanced glycation end products receptors; ROS, reactive oxygen species; SCFAs, short chain fatty acids; SOD, superoxide dismutase; TGF, transforming growth factor; Th, T helper; ThF, T helper follicular; TLRs, toll-like receptors; TNF, tumor necrosis factor; Treg, T regulatory; VAT, visceral adipose tissue; VDR, vitamin D receptor; YHEI, youth healthy eating index. the prenatal and perinatal period seems to predispose to obesity in postnatal life stages (10). Children born from diabetic mothers or mothers who smoked during pregnancy are more exposed to the risk of obesity and type 2 diabetes (11). Also, breastfeeding seems to reduce the risk of overweight/obesity. In addition, the so-called "obesity rebound" at 5-7 years old seems to be very critical for the development of obesity and risk of obesity in adulthood (10). Puberty is another critical period in life especially in females, in terms of obesity risk since early menarche ( $<11$ years) in females predisposes to obesity in a more remarkable way than later menarche ( $>14$ years) (10). In these females, early menarche leads to obesity in adolescence and in adulthood, while in $70 \%$ of obese adolescent males weight tends to normalize at later ages in comparison to $20 \%$ of obese adolescent females.

From a genetic point of view, humans have acquired the ability to deposit fats and utilize them under a condition of starvation. However, this characteristic turned into a disadvantage in western societies where the abundant consumption of food leads to an increase of fat deposits. As far as nutritional factors are concerned (12), evidence has been provided that obese children consume more fat than non-obese children, thus leading to higher body mass index (BMI). In addition, fats tend to deregulate control mechanisms for body weight thanks to a greater amount of energy per gram they provide. Fats are more palatable with a smaller satiating effect in comparison to proteins and sugars and the actual amount ingested. Another nutritional aspect in obese children and adolescent is the irregular eating pattern with a lower frequency of breakfast consumption.

Physical activity (PA) represents another important factor in the development of obesity since reduced PA correlates with excess body weight (12). Sedentary life due to playing video-games and watching television affects basal expenditure. In particular, watching television also increases calorie intake for consumption of 
foods which, in turn, are publicized by the same programs children are watching. Finally, an association has been found between short sleep and obesity in the sense that sleep duration is inversely associated to BMI and waist circumference.

The excess of fat negatively influences health and/or wellbeing in children. Data reported by Freedman and associates (13) demonstrated that childhood obesity is associated to the risk of cardiovascular events in adult life. In addition, Lauer and associates (14) described some factors affecting the relationship between childhood and adult cholesterol levels with special reference to early development of atherosclerosis in children. Metabolic (high levels of triacylglycerols, low levels of high density lipoproteincholesterol) and clinical modifications (high blood pressure and defective glucose metabolism) are part of the MetS, which represents one of the major complications of childhood obesity (15). For instance, type 2 diabetes and cardiovascular disease represent sequelae of MetS.

On these grounds, the aim of the present review is to describe the profile of the immune response in obese children, taking into consideration that obesity is an "inflammatory" disease. Furthermore, interventional studies aimed at preventing obesity and/or attenuating the immune-inflammatory profile will be illustrated.

\section{IMMUNITY IN CHILDHOOD OBESITY}

Obesity is associated to a condition of systemic inflammation, on the one hand (16), and to an impaired immunity, on the other hand (17). For instance, obese individuals were more susceptible to the H1N1 influenza during the 2009 pandemia (18). In obese individuals, visceral adipose tissue (VAT) is the major source of pro-inflammatory cytokines, which, in turn, lead to insulin resistance $(16,19)$. Experimentally, obese animals produce higher amounts of adipose tissue-derived tumor necrosis factor (TNF) $-\alpha$ in comparison to the lean counterpart (20), while in obese humans Pradhan and associates (21) documented the association between C-reactive protein, interleukin (IL)-6, and the risk of developing type 2 diabetes. Quite interestingly, macrophages with an inflammatory phenotype have been detected in the context of VAT of obese people $(22,23)$. They account for $40-60 \%$ of VAT immune cells in obesity and differ from the phenotype of macrophages contained in lean adipose tissue $(22,23)$. Obesity-associated macrophages in VAT are M1 "classically activated macrophages." They secrete in large amounts TNF- $\alpha$, IL-6, IL-12, IL-1 $\beta$, and monocyte chemotactic protein-1 (MCP-1), as well as nitric oxide (NO) (24). On the contrary, in lean VAT M2 macrophages are "alternatively activated macrophages," which secrete IL-10, IL-1 receptor antagonist, and arginase 1, thus exerting anti-inflammatory activities. The contingent of obesity VAT macrophages seems to be in part residential or, in alternative, migrates into VAT from remote sites under the effect of MCP-1. M1 macrophages seem to favor insulin resistance and in murine models their deactivation protects against insulin resistance $(25,26)$. Of note, VAT macrophages and adipocytes share common functions in terms of pattern of cytokine released and insulin resistance induction (27). It is worthwhile mentioning that, in obese mice, neutrophils and mast cells also play an inflammatory role, while the number of eosinophils is decreased (28). The above described cellular profiles promote insulin resistance in murine obesity (28).
As far as adaptive immune responses are concerned in obese mice, VAT contains higher numbers of $\mathrm{T}$ helper (Th) CD4+, T cytotoxic CD8+ cells, and B cells. In particular, Th1 cells produce interferon (IFN) $-\gamma$ in vitro (29). IFN- $\gamma$, in turn, polarizes M1 macrophages, also increasing release of TNF- $\alpha$.

Conversely, obese mice lacking IFN- $\gamma$ expression or T-cell receptor $\beta$-deficient mice are more protected with regard to inflammatory cell infiltration of VAT $(29,30)$. T regulatory (Treg) cells are decreased in both obese mice and humans $(31,32)$. In murine VAT, depletion of Treg cells led to increased insulin levels and reduced insulin receptor signaling (32). On the other hand, expansion of Treg cell contingent in high-fat-diet-fed mice and increased secretion of IL-10 led to a significant reduction of blood glucose levels, insulin resistance, and glucose tolerance. These data suggest the anti-inflammatory role exerted by Treg cells via release of IL-10, which suppresses obesity-induced inflammation. Han and associates (33) have reported that insulin bears receptors on Treg cells, thus decreasing IL-10 release by activating AKT/mammalian target of rapamycin signaling pathway. These results suggest that high insulin levels in obesity play an inflammatory role by impairing Treg cell-induced suppression.

Th17 cells are increased in obese mice and in humans, thus leading to enhanced expression and release of IL-17 (34-36). However, evidence has been provided that $\gamma \delta \mathrm{T}$ cells and neutrophils can also produce IL-17 and, therefore, Th and Th17 cells are not the only source of this cytokine $(37,38)$. According to Zúñiga (37), these various sources of IL-17 may explain some contradictory results obtained in IL-17 knockout mice which are overweight and become obese as results of a high-fat diet compared to controls. Despite these controversial results in mice, there is evidence that obesity is associated to autoimmune diseases in both mice and humans likely via a Th17-dependent mechanism (39). Finally, as recently reported by Erbel and associates (40), IL-17A plays a pathogenetic role in advanced murine and human atherosclerosis, which is a complication of the obese status.

CD8 + cells accumulate into VAT in murine obesity and their depletion led to reduction of macrophage infiltration and amelioration of insulin sensitivity $(41,42)$. Adoptive transfer of CD8+ cells into CD8-deficient mice increased inflammatory cytokine production in the context of VAT. Jiang and associates (43) have documented that CD8+ cells in VAT are activated by IFN- $\gamma$ released by Th1 cells and, moreover, they express high levels of the integrin CD11a, which promotes infiltration of CD8+ cells into VAT.

B-cell infiltration into VAT seems to precede $\mathrm{T}$ cell and macrophage homing into this tissue. According to Winer and associates (44), B cells into VAT provoke insulin resistance, modulating $\mathrm{T}$ cells and producing immunoglobulin (Ig)G, which account for insulin resistance. Conversely, obese B null mice lack inflammatory cytokines, produce high levels of IL-10, and are protected against insulin resistance.

Major features of immune alterations in obese people are indicated in Table 1.

\section{THE IL-10/IL-17 RATI0 AND TYPE OF DIET}

In recent years, it has become clear that some lifestyle factors, including dietary habits, alcohol consumption, exercise, and 
Table 1 | Alterations of innate and adaptive immunity in human obesity.

VAT tissue produces pro-inflammatory cytokines, which are responsible for insulin resistance $(16,19)$

The association between C-reactive protein, IL-6, and the risk of developing type 2 diabetes has been documented (21)

M1 macrophages with an inflammatory phenotype have been found in obese people VAT $(22,23)$

T regulatory cells are decreased in human obesity $(31,32)$

Th17 cells are increased in obese humans (34-36)

CD8+ cells express high levels of the integrin CD11a, which promotes their infiltration of CD8+ into VAT (43)

$B$ cells into VAT provoke insulin resistance, modulating $T$ cells and producing immunoglobulin $\mathrm{gG}$, which account for insulin resistance (44)

smoking play an important role in the control of both postprandial lipemia and inflammation. Advancing data suggest that dietary anti-oxidants may influence both metabolic and inflammatory markers linked to low-grade systemic inflammation (45, 46). In general terms, low-grade inflammation seems to be determined by the ratio between IL-17 and IL-10. IL-17 has been associated to the pathogenesis of multiple autoimmune diseases, such as rheumatoid arthritis, multiple sclerosis, and inflammatory bowel diseases (47). IL-17 also plays a crucial role in host defense upon bacterial and fungal infections by recruiting neutrophils and producing antimicrobial peptides (AMPs) (48). Th17 cells release multiple molecules of IL-17 (A-F) (49) and IL-17F was also found to be co-expressed in Th17 cells, thus contributing to host defenses, inflammatory, allergic, and autoimmune functions of Th17 cells (50).

Interleukin-10, a product of Treg cells (51) inhibits cytokine production, particularly IFN $-\gamma$ by $\mathrm{T}$ and natural killer (NK) cells, and proliferation of $\mathrm{T}$ cells, performing primarily at the level of antigen-presenting cells (52). IL-10 also inhibits other monocyte/macrophage functions, including oxidative burst, NO, pro-inflammatory cytokine production, and cytotoxicity (53).

The relationship between dietary habits and IL-10/IL-17 ratio in children has been stressed out in a recent paper (Vitale et al., submitted). Schoolchildren with normal weight received healthy eating recommendations and, then, BMI values, PA, and levels of salivary IL-17 and IL-10, respectively, were followed-up at enrollment, after 6 months and after 1 year (Vitale et al., submitted). Results of this follow-up demonstrated that increase in BMI and reduced PA was associated to a decrease in IL-10 and an increase in IL-17 salivary levels in one group of children. In the other group characterized by reduction in BMI and increase in PA, IL-10 salivary levels were higher than those detected in the case of IL-17. Variations in BMI were oscillating within normal ranges.

With special reference to healthy food recommendations provided to children involved in this trial (Vitale et al., submitted), they are in agreement with those elaborated by the American Heart Association for children aged 2 years and older (54). The suggested diet relies on fruits and vegetables, whole grains, lowfat and non-fat dairy products, beans, fish, and lean meat. These

\section{Table 2 | Type of diet and IL-10/IL-17 ratio}

Normal weight children who attended dietary recommendations and practiced PA exhibited a reduction of BMI and an increase in IL-10 salivary levels and a decrease in IL-17 salivary levels (Vitale et al., submitted)

Normal weight children who did not attend dietary recommendations and did not practice PA exhibited an increase in BMI and in IL-17 salivary levels while IL-10 salivary levels were decreased (Vitale et al., submitted)

general recommendations associated to other recent dietary guidelines $(55,56)$ are primarily based on low intakes of saturated and trans fat, cholesterol, added sugar and salt, energy intake, and PA according to the Mediterranean diet (MedDiet) model (57, 58). In this framework, Knoops and associates (59) have shown that in European men and women aged 70-90, adherence to a Mediterranean-style diet was associated to a lower rate of all-cause mortality. Taken together, the combination was associated to a mortality rate of about one-third of those with none or only one of these protective factors. In a large prospective survey involving about 22,000 Greek adults, adherence to a Mediterranean-style diet and death was associated to approximately $2 / 9$ increment in the MedDiet score with a $25 \%$ reduction in total mortality (60).

There is experimental evidence that a combination of diet and exercise reduces adipose tissue derived-inflammation and macrophage involvement $(61,62)$.

In the above mentioned study (Vitale et al., submitted), increased levels of IL-17 in children with higher BMI seem to be responsible for a low-grade inflammation attributable to the intake of hypercaloric food [junk food; see also Ref. (59)] and reduced PA. Instead, in children with lower BMI, elevated IL-10 levels support an anti-inflammatory status, likely dependent on the strict adherence to healthy dietary recommendations and PA. In this framework, it is worthwhile mentioning that post-prandial stress is associated to a condition of low-grade inflammation (63) with a massive increase of free radicals and pro-inflammatory cytokines (64). In the long run, inflammatory mediators might cause damage of intestinal barrier function, leading to endotoxin leakage into the portal blood (32). Increased endotoxin levels, in turn, might provoke weight gain, insulin resistance, and a higher degree of inflammation, a condition referred to as "metabolic endotoxemia," also associated to cardiovascular disease (65).

The major achievements related to the relationship between dietary habits and IL-10/IL-17 ratio in normal weight children are summarized in Table 2.

\section{OXIDATIVE STRESS IN OBESITY}

Obesity is associated to excessive production of reactive oxygen species (ROS) from different sources such as mitochondrial respiratory chain and nicotinamide adenine dinucleotide phosphate (NADPH) oxidase (66-69). This event leads to the development of insulin resistance and MetS, thus deregulating adipokine and pro-inflammatory cytokine release.

In obese mice with insulin resistance, an adipocyte fatty acidbinding protein has been identified, which is modified by 4 hydroxynonenal, a lipid peroxidation-derived aldehyde (70). Thus, adipose proteins, which play a role in cellular stress, lipotoxicity, 
or insulin signaling are carbonylated as a result of the oxidative process. Furthermore, in obese mice programed by early weaning, a series of metabolic disturbances were detected such as visceral adiposity, hypertension, dyslipidemia, hepatic steatosis, and high concentrations of hepatic triglycerides (70). These alterations were associated to plasmatic and hepatic oxidative stress supported by elevated amounts of thiobarbituric acid-reactive substances (markers of lipid peroxidation) and decreased activities of superoxide dismutase (SOD) and glutathione peroxidase. This experimental model is an example of the link between obesity and oxidative stress. In another study, evidence has been provided that malondialdehyde (another biomarker of lipid peroxidation), carbonylated proteins, and SOD activity were increased in testicular tissue and serum of obese rats (71).

In humans, studies by Keaney and associates (72) have clearly demonstrated the association between oxidative stress and obesity by monitoring urinary isoprostanes, which are a reliable index of oxidative stress in vivo (73). Of note, weight loss due to dietary changes and increased PA was able to significantly reduce urinary levels of the isoprostane 8-epi-prostaglandin F2- $\alpha$, thus supporting the link between obesity and oxidative stress (74).

From a pathogenic point of view, evidence has been provided that hydrogen peroxide-induced oxidative stress leads to the differentiation of pre-adipocytes into adipocytes via transcription factors such as CCAAT/enhancer-binding protein- $\beta$ and peroxisome proliferator-activated receptors- $\gamma$ (75). Another molecule, protein kinase $\mathrm{C}(\mathrm{PKC})$, is involved in the adipocyte differentiation (76). In fact, PKC deficiency increases fatty acid oxidation and reduces fat storage or its loss protects obese mice against hepatic steatosis and insulin resistance $(77,78)$.

On the other hand, obesity can induce oxidative stress in adipocytes via production of ROS by mitochondria which can be increased in response to a high-fat diet $(79,80)$. In this framework, it has been reported that mitoNEET present in the outer mitochondrial membrane causes increased lipid storage, thus augmenting the mass of murine adipose tissue and, ultimately, leading to obesity (81). Quite interestingly, NOX-2 (the catalytic core of NADPH oxidase) has been found to be over-expressed in hypercholesterolemic and obese children (82). In these children, the enhanced NOX-2-dependent oxidative stress and reduction of flow-mediated arterial dilation indicated a condition of endothelial dysfunction. In addition, the increased oxidative stress in obese people decreases the production of adiponectin, an adipokine which inhibits plasminogen activator inhibitor (PAI)1 , IL-6, and TNF- $\alpha$ (83). Adipocyte-induced increase of TNF$\alpha$ and PAI-1 is responsible for a prothrombogenic status and insulin resistance in obese people $(20,84)$. Finally, inhibition of adiponectin production increases insulin resistance and promotes atherosclerosis $(85,86)$.

According to Furukawa and associates (83), adipocytes produce ROS and the resulting oxidative stress is able to induce insulin resistance in skeletal muscle and adipose tissue and decreased secretion of insulin by pancreatic $\beta$ cells, thus, generating atherosclerosis and hypertension. Furthermore, oxidative stress and hyperglycemia generate advanced glycation end products (AGEs). They bind to cellular receptors [advanced glycation end products receptors (RAGEs)], thus contributing to the condition of low-grade inflammation in obesity (87). In addition, a deficit of soluble RAGEs in obesity has been associated to low levels of adiponectin and increased oxidative stress (88).

The effects of oxidative stress in human obesity are outlined in Table 3.

On these grounds, in a recent report (89), salivary NO concentration was determined in overweight/obese children, and, then, compared to that of normal weight and underweight counterparts. In children, eating was assessed by considering the youth healthy eating index (YHEI) (90) and compared to BMI, activity/inactivity, and salivary NO concentration. Data documented that in overweight/obese individuals, BMI positively correlated to YHEI scores, inactivity, and NO concentration, respectively, while BMI inversely correlated to PA. Previous studies have demonstrated the role of PA in the prevention of obesity $(91,92)$. In addition, in the HELENA project (93), it has been demonstrated that more physically active and leaner children undergo higher energy intake than that observed in less active adolescents with more fat-mass. The progressive increase in body weight results from a daily cumulative effect of even a small caloric excess, which may be related to the reduction of PA (94). Data previously discussed (89) as well as other epidemiological studies confirm the inverse relationship between PA and BMI $(95,96)$. The findings related to the increase in salivary NO concentration in overweight/obese children (89) are in accordance with a series of reports (97-100) in which various other biomarkers were monitored for assessing the inflammatory profile in obesity (101). Particularly, NO participates to inflammation as a product of M1 macrophages, whose activities are depending on TNF- $\alpha$, IL-1 $\beta$, and IL-6 release (102-104). In this direction, detection of salivary NO in overweight/obese children may be interpreted as a biomarker of inflammation. However, other studies have found no modifications of NO levels in obese children (105).

\section{IMMUNE PROFILE IN CHILDHOOD ASTHMA AND OBESITY}

Evidence has been provided that a correlation exists between obesity and asthma in children $(106,107)$, which is often independent from allergic sensitization, in accordance with same observation in adults (108).

Asthma incidence in children may be ascribed to air pollution, environmental tobacco smoke, infectious agents, and detrimental dietary habits (109).

\section{Table 3 | Oxidative stress and human obesity.}

Oxidative stress decreases the release of adiponectin with an increase in TNF- $\alpha$ and PAI-1, thus leading to a prothrombogenic status and insulin resistance (83)

In obese children, the overexpression of NOX-2 and dependent oxidative stress suggests a condition of endothelial dysfunction (82)

Adipocytes produce ROS, thus leading to decreased secretion of insulin by pancreatic $\beta$ cells which is associated to atherosclerosis and hypertension (83)

Generation of AGEs in response to oxidative stress and hyperglycemia contributes to low-grade inflammation and low levels of adiponectin in the presence of a deficit of soluble RAGEs $(87,88)$ 
Adipokines such as leptin, adiponectin, resistin, and visfatin have been object of interest in childhood obesity and asthma clinical manifestations. Leptin is a plasma protein involved in the regulation of food intake (110) and is able to exert pro-inflammatory effects on dendritic cells (DCs), NK cells, T cells, B cells, and Treg cells (111). Adiponectin exerts anti-inflammatory activities, inhibiting IL- 6 and TNF- $\alpha$ production (112). Resistin is expressed in human macrophages, bone marrow, spleen, and peripheral lymphomonocytes and at low levels in adipose tissue (113). It is able to activate $\mathrm{NF}-\kappa \mathrm{B}$, thus promoting a pro-inflammatory cytokine release. Visfatin, known as a pre-B-cell colony-enhancing factor, is able to exert insulin-mimetic effect $(114,115)$. In addition, visfatin has been shown to induce chemotaxis of phagocytes as well as production of IL-1, TNF, IL-6 (116).

On these bases, Magrone and associates (117) have investigated the immunological mechanisms involved in asthma and obesity in terms of cytokine and adipokine release. Eighty children were enrolled and were divided into four groups: asthmatic obese, obese, asthmatic, and control children. For each group, BMI was calculated and asthma was defined following the Global Initiative for Asthma (GINA) Guidelines (118). IL-2 and IFN- $\gamma$ serum levels were higher in asthmatic obese children than those of controls. IL-4 serum levels were undetectable, while IL-13 serum levels were not statically significant between groups. On the other hand, IL-1 $\beta$, IL-6, and IL- 8 serum levels were increased in asthmatic obese and obese children in comparison to asthmatic children and controls.

With regard to adipokines, leptin serum levels were higher in obese and asthmatic obese in comparison to asthmatic children and controls. Conversely, a significant reduction of serum adiponectin levels particularly in asthmatic obese children was detected. In conclusion, one can hypothesize that increased levels of leptin may account for the enhancement of Th1 responses (119), while adiponectin reduction may be responsible for a diminished release of IL-10 by Treg cells (120), thus worsening the pro-inflammatory status.

The immune profile in obese asthmatic children is illustrated in Figure 1.

\section{ROLE OF INTESTINAL MICROBIOTA IN OBESITY}

Evidence has been provided that intestinal microbiota composition is altered in obese people, even including children, as recently reviewed by Kabat and associates (121). Accordingly, intestinal microbiota is active on both innate and adaptive immunity. With regard to innate immunity, commensal bacterial products [e.g., lipopolysaccharides (LPS)] bind to Toll-like receptors (TLRs) and Nod-like receptors present on gut immune and non-immune cells. LPS, then, binds to TLR-4 on epithelial cells, soliciting release of the AMP ASReg III- $\gamma$. This AMP is also produced by lamina propria (LP) DCs via TLR-5 stimulation, which in turn, secrete IL-23, an inducer of IL-22 producing Th17-type cells. The role of IL-22, in this context is to amplify the release of other AMPs in the gut (121). Furthermore, digestion of plant polysaccharides by microbiota gives rise to short chain fatty acids (SCFAs), which, in turn, induce release of IL-18 from intestinal epithelial cells via binding to the G-protein coupled receptor (GPCR). Among SCFAs, acetate seems to protect epithelial barrier function, mediating an anti-apoptotic

\section{First pathogenetic mechanism}

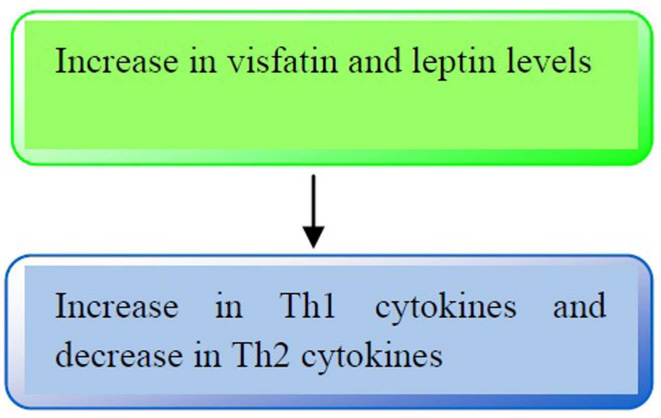

\section{Second pathogenetic mechanism}

FIGURE 1 | Pathogenetic mechanisms involved in the immune profile in asthmatic obese children. First pathogenetic mechanisms: increased production of visfatin and leptin serum levels may lead to an increased release of Th1 cytokines (IL-2, IFN- $\gamma$ ) and a decreased release of Th2 cytokines (IL-4, IL-13), respectively. Second pathogenetic mechanism: adiponectin reduces the activation of Treg cells and increases pro-inflammatory cytokines production (IL-1 $\beta$, IL-6, and IL-8).

response. Taken together, all these gut microbiota-elicited activities seem to be protective to the host.

With special reference to the adaptive immunity, microbiota actively participates to intestinal IgA production via release of $\mathrm{B}$-cell activating factor, a proliferation-inducing ligand and transforming growth factor (TGF)- $\beta$ by intestinal epithelial cells and DCs, thus leading to differentiation of B cells into IgA-producing plasma cells. Also, follicular DCs promote differentiation of IgAproducing plasma cells, as main producers of TGF- $\beta$ in the Peyer's patches (PP). Moreover, interaction between Th17-like cells and DCs favors IgA production within PP. Th17-like cells also promote T-cell homing to the LP via soluble form of LTa3 lymphotoxin, thus affecting $\mathrm{T}$ helper follicular (ThF) cell function. Also ATP, generated by certain commensals, contributes to the induction of Th17 cells which, in turn, differentiate into ThF cells, thus promoting IgA production within PP. Polysaccharide A (PSA) from Bacteroides fragilis, SCFAs, and TGF- $\beta$ induced by Clostridia (IV, XIVa, XVII) promote Treg cell differentiation in the colon. PSA acts on TLR-2 exposed on DCs, while SCFA operate via GPCR43 signaling (121). From these data, it is evident that microbiotainduced IgA production and Treg cell differentiation in the gut confers protection under healthy circumstances.

The altered microbiota in obesity subverts the protective mechanisms above illustrated. For instance, increase in segmented filamentous bacteria induce release of serum amyloid A by epithelial cells which acting upon DCs leads to differentiation and induction of Th17 cells endowed with inflammatory activities $(122,123)$. 
Furthermore, there is evidence that modifications of microbiota composition in early life may increase the risk to developing obesity in later life. For instance, children delivered by caesarian section exhibit higher risk to become obese in adolescence when compared to children born by vaginal delivery (124). Furthermore, breast-milk-fed children have less risk to become obese than infant formula-fed children (125). Also, exposure of antibiotics in early life may alter the composition of microbiota as observed in mice which underwent changes in hepatic lipid and cholesterol metabolism, thus leading to adiposity (126). In humans, a correlation has been found between early-life antibiotic use and obesity (127) and other studies have documented that presence/absence of specific microbiota components can modulate immune response (128).

\section{INTERVENTIONAL STUDIES IN CHILDHOOD OBESITY}

Prevention seems to be the most appropriate strategy to combating obesity epidemic. According to a number of reports, there are some major factors to be considered in the prevention of obesity development (129-132). For instance, maternal factors encompass monitoring of weight before conception and during pregnancy. Breastfeeding may represent a favorable factor in terms of reduced risk of obesity.

Dietary factors are based on limited consumption of sugarsweetened beverages and meals with servings of vegetable and fruits, avoiding fast foods, and encouraging limited portions of food.

Physical activity is based on levels of activity from moderate to vigorous for one or more hours/day. Sedentary activity (television, play station) should be limited to less than $2 \mathrm{~h}$ /day after age two. Settings where food and PA can be influenced are represented by schools and preschool institutions as well as after-school care services. Built environment encompasses walking and cycling networks, parks, and recreation facilities. Home environment should also be studied as a possible factor of obesity prevention but the limitation is represented by the heterogeneity of homes and possibility of access.

\section{PREBIOTICS}

By definition, prebiotics are non-digestible dietary fibers, which are able to stimulate both growth and activity of gut bacteria. The anti-obesogenic effects of prebiotics have mostly been evaluated in experimental studies. In prebiotic-fed genetically obese mice reduction of circulating endotoxins, pro-inflammatory cytokines and intestinal permeability was reported (133). In rats with steatohepatitis induced by a high-fat diet, lactulose treatment reduced liver inflammation and endotoxemia (134). Human clinical trials based on the effects of prebiotics on obesity development are very scanty. In infants receiving formula enriched in prebiotics (galacto-oligosaccharides and fructo-oligosaccharides at 9:1 ratio), an increase in Bifidobacteria was reported, thus suggesting the possibility to influence adipocyte growth via modulation of microbiota composition (135). In patients with nonalcoholic steatohepatitis (NASH), administration of oligofructose reduced serum aminotransferases and insulin levels (136). Of note, in western countries NASH is very common in obese children (137).

\section{PROBIOTICS}

Various strains of bacteria have been found in the gut of obese and lean humans and, according to recent data, it seems that just smaller modifications of intestinal commensals may account for weight gain (138). On the other hand, in overweight adolescents, the response to diet and PA was dependent on the microbiota composition present before treatment (139). In this direction, gut bacteria such as Ruminococcus bromii and Eubacterium rectale were prevalent in individuals under a diet rich in resistant starch who responded to a dietary weight loss program (140). Furthermore, Lactobacillus (L.) gasseri SBT2055 (LG2055) administration to overweight subjects could lead to a significant reduction of abdominal adiposity (141).

Just recently, fecal microbiota transplantation has been applied to patients with inflammatory bowel disease and obese patients (142). In particular, transfer of intestinal microbiota from lean donors to obese recipients attenuated clinical manifestations of MetS (143).

With special reference to pediatric obesity, the ratio between Bacteroidetes and Firmicutes seems to play a role in weight gain (144). Also, the size of Enterobacteriaceae, such as Desulfovibrio and Akkermansia (A.) muciniphila were found to be related to pediatric obesity (145). These last findings are also supported by experiments in obese mice which underwent reduction of fat-mass gain, endotoxemia, adipocyte-induced inflammation, and insulin resistance following treatment with $A$. muciniphila (146).

Other clinical trials in pregnant mothers have documented that administration of L. rhamnosus 4 weeks before expected delivery up to 6 months after delivery could limit excessive weight gain during the first 2 years of life but not between 2 and 4 years (147). However, maternal supplementation with probiotics in the first trimester of pregnancy did not modify prenatal and postnatal growth rates $(148,149)$. In this framework, evidence has been provided that milk from obese mothers is enriched in Staphylococcus and Lactobacillus with lower counts of Bifidobacterium when compared to that of normal weight women over the first 6 months of breastfeeding (150). The role of milk microbiota on the development of neonatal microbiota needs to be further investigated.

Synbiotics are a mixture of pro- and prebiotics which, when ingested, are able to modulate gut microbiota and intestinal immunity (151). In a recent clinical trial, Kelishadi and associates (152) have administered overweight children with a synbiotic (ProtexinLondon, England) composed by a combination of viable Lactobacilli of human origin and fructo-oligosaccharides, as prebiotics. Treated subjects exhibited a significant reduction in weight as well as in TNF- $\alpha$ and IL- 6 with an increase in adiponectin in comparison to the placebo group. However, the modifications of inflammatory markers were dependent on weight reduction.

\section{FATTY ACIDS}

Fatty acids exert important biological functions in the body as a substrate for energy and the formation of membranes, also acting as regulators of genetic expression (153). Excessive consumption of saturated fatty acids or an altered ratio between omega-3 polyunsaturated fatty acids (n-3 PUFAs) and n-6 PUFAs leads to obesity, diabetes, neurodegenerative disease, and cancer 
(154, 155). n-3 PUFAs and their derivatives, eicosapentaenoic acid (EPA) and docosahexaenoic acid (DHA), are able to reduce plasma triglyceride levels and body weight (156, 157). Furthermore, n-6 PUFAs promote excessive adipose tissue growth, while n-3 PUFAs inhibit adipogenesis, while promoting storage and accumulation of mature adipocytes (158-162). In terms of early interventions at the level of maternal inflammation, studies in transgenic Fat-1 mice have documented that increase in $n-3 / n-6$ PUFA ratio diminished fetal-placental lipid exposure, thus limiting adverse metabolic effects in adult offsprings (162). This therapeutic model may be applied for preventive therapy in obese pregnant women. However, as stated in a recent review by Hauner and associates (163), results on the prevention of childhood obesity obtained through modification of fatty composition during pregnancy and lactation are still contradictory and inconsistent.

In a very recent paper (164), it has been reported that consumption of n-3 PUFAs in obese adolescents along with dietary restriction improved anthropometric parameters, while decreasing plasma triglyceride levels. These effects correlated to a reduced hypoxia in subcutaneous adipose tissue (164).

\section{POLYPHENOLS}

Polyphenols encompass flavonoids and non-flavonoids (resveratrol) compounds, which are widely distributed in the vegetal kingdom. They are mostly contained in fruits, vegetables, and cereals, and, therefore, contained in large amounts in MedDiet (165).

Polyphenols are endowed with anti-oxidant and antiinflammatory activities and moderate consumption of red wine has been shown to prevent cardiovascular disease according to the French paradox (166-168). Experimentally, administration of resveratrol from red grapes to obese rats reduced visceral obesity and triglycerides and low-density lipoprotein plasma concentration, thus decreasing the risk of hypertension, dyslipidemia, and steatosis (169). Furthermore, flavonoids hampered both transcription factors and differentiation of pre-adipocytes into mature adipocytes (170). The in vitro demonstration that polyphenols from fermented grape marc differentiate and activate peripheral human Treg cells further supports the anti-inflammatory role of these natural compounds (171). Just recently, evidence has been provided that cocoa power supplementation ameliorated the proinflammatory profile in high fat-fed obese mice (172). Same results have been obtained with the administration of epigallocatechin-3gallate (EGCG) in high fat-fed mice (173). In obese women administration of green tea (EGCG) did not affect body weight, fat-mass, energy, homeostasis, cardiometabolic risk factor, and liver function (174). Also, results by Li and associates (175) demonstrated that green tea supplementation did not influence blood pressure among overweight and obese adults. Conversely, in normal weight obese syndrome subjects, regular consumption of dark chocolate was useful in maintaining a good atherogenic profile for its effects on HDL cholesterol, lipoprotein ratios, and inflammatory markers (176).

In general terms, consumption of natural oxidants contained in polyphenols with the diet may afford protection against cardiovascular disease acting upon lipid profile, endothelial function, and inflammatory mediators $(177,178)$.

\section{MELATONIN}

Melatonin is a pineal hormone endowed with anti-oxidant properties, thus, preventing nitro-oxidative stress mediated by peroxynitrites (179). Melatonin also exhibits anti-inflammatory activities inhibiting ciclooxygenase- 2 and inducible NO synthase and acting upon transcriptional pathway involved in inflammation, such as NF- $\mathrm{B}$, AP-1, Nrf2, as well as PI3K/Akt and MAPK kinase (180, 181). In view of its beneficial activities, melatonin has successfully been used in rats with MetS diminishing insulin resistance, release of TNF- $\alpha$ and IL-6 from adipocytes, low-density lipoprotein, and very low-density lipoprotein plasma levels and body weight (182). Evidence has been provided that melatonin can promote weight loss in rodents via browning of white adipose tissue (183) and this may represent a new approach to treat human obesity (184). In fact, melatonin is a non-toxic compound widely distributed in foodstuffs, such as olive oil, wine, coffee, tea, walnuts, and grapes. Experimentally, a combination of resveratrol and melatonin afforded protection in a model of myocardial infarction (185). In this context, over the past few years, some clinical trials have documented the beneficial effects of melatonin in patients with MetS in terms of amelioration of blood pressure, lipid pattern, and oxidative stress markers (186-188).

\section{VITAMIN D}

Vitamin D exerts anti-inflammatory activities, acting on DCs, which in turn, induce activation of Treg cells. This vitamin possesses specific receptors, so-called Vitamin D receptors (VDR), on gut epithelial and immune cells, while bacterial colonization seems to affect distribution and expression of VDR (189). In humans, vitamin D deficiency has been associated to asthma and increased BMI (190-192). Furthermore, it has been hypothesized that gut microbiota and vitamin D may be linked cofactors in the pathogenesis of childhood asthma and obesity (193).

On these grounds, vitamin D may represent another possible target of interventional studies in asthma-obesity but birth cohort studies based on maternal and neonatal diet, gut microbiome, immune response, and vitamin D-mediated immune regulation are needed for asthma/obesity prevention.

The major nutritional attempts to prevent/attenuate childhood obesity are illustrated in Table 4.

\section{CONCLUSION}

Nowadays, obesity is an epidemic in western and westernized societies, thus representing one of the major consequences of food-related disease (196). Besides appropriate dietary habits and $\mathrm{PA}$, an anti-inflammatory profile in response to food antigens should be maintained throughout life span. For instance, postprandial low-grade inflammation is normally compensated by dietary components, e.g., polyphenols, which activate gut Treg cells (197).

A continuous intake of junk food since childhood may account for the outcome of a systemic inflammation in overweight/obese adults.

In interventional studies, another important aspect is represented by the identification of gut microbial components involved in the development of obesity. In view of the diversity of human intestinal microbiota (198), its variations among different obese 


\section{Table 4 | Some effects of natural products on obese humans.}

Prebiotics, non-digestible dietary fibers, which are able to stimulate both growth and activity of gut bacteria (194), induce increase in Bifidobacteria in infants (135) and decrease in serum aminotransferases and insulin levels in NASH (136)

Probiotics, live bacteria, which when administered in adequate amounts confer a health benefit to the host (195). Administration of L. gasseri to overweight subjects reduced abdominal adiposity (141). Fecal microbiota transplantation attenuated clinical manifestation of MetS (143).

L. rhamnosus administration to pregnant mothers limited excessive weight gain during the first 2 years of life (147). Synbiotic administration to overweight children reduced weight gain and pro-inflammatory cytokine release (152)

n-3 Polyunsaturated fatty acids consumption in obese adolescents along with dietary restriction improved anthropometric parameters, while decreasing plasma triglyceride levels. These effects correlated to a reduced hypoxia in subcutaneous adipose tissue (164)

Polyphenols (flavonoids and non-flavonoids compounds) present in fruits vegetable and cereals exert anti-inflammatory and anti-oxidant activities (165)

Melatonin, a pineal hormone, has been shown to be protective in patients with MetS in terms of improvement of blood pressure, lipid profile, and oxidative biomarkers (186-188)

Vitamin D deficiency has been associated to asthma and increased BMI and, therefore, together with gut microbiota alterations may lead to childhood asthma and obesity outcome (193)

individuals should be investigated also in terms of interpersonal microbiome differences (199). For instance, in the case of treatment with probiotics generating a smaller effect size, the personal microbiome effect which is very large may mask the more feeble effects of treatment. Therefore, methods for the study of microbiome should be borrowed from the scientific areas and adjusted for analyzing massive data as in the case of obese people.

In conclusion, more appropriate diets (e.g., MedDiet) or supplements containing natural products (polyphenols, n-3 PUFA, vitamins, synbiotics) are highly recommended to prevent or attenuate the noxious effects of obesity. In this last regard, in a very recent review, Casas and associates (200) have stressed out the immune protective effect of MedDiet, which may act on various immune biomarkers, such as molecules involved in the stability of atheromatous plaque.

\section{ACKNOWLEDGMENTS}

TM is a recipient of a contract in the context of the project "Bioscience and Health (B\&H)" (PONa3_00395). This paper was in part supported by a grant from PON02_00186_2937475 (PRO.ALI.FUN.).

\section{REFERENCES}

1. International Association for the Study of Obesity. Obesity the Global Epidemic (2013). Available from: http://www.iaso.org/iotg/obesitytheglobalepidemic

2. Nicklas TA, Baranowski T, Cullen KW, Berenson G. Eating patterns, dietary quality and obesity. J Am Coll Nutr (2001) 20:599-608. doi:10.1080/07315724. 2001.10719064
3. Parsons TJ, Power C, Logan S, Summerbell CD. Childhood predictors of adult obesity: a systematic review. Int J Obes Relat Metab Disord (1999) 23:S1-107.

4. Whitaker RC, Wright JA, Pepe MS, Seidel KD, Dietz WH. Predicting obesity in young adulthood from childhood and parental obesity. N Engl J Med (1997) 337:869-73. doi:10.1056/NEJM199709253371301

5. Lobstein T, Baur L, Uauy R; IASO International Obesity TaskForce. Obesity in children and young people: a crisis in public health. Obes Rev (2004) 5:4-104. doi:10.1111/j.1467-789X.2004.00133.x

6. Popkin BM, Gordon-Larsen P. The nutrition transition: worldwide obesity dynamics and their determinants. Int JObes Relat Metab Disord (2004) 28:S2-9. doi:10.1038/sj.ijo.0802804

7. Wang Y, Lobstein T. Worldwide trends in childhood overweight and obesity. Int J Pediatr Obes (2006) 1:11-25. doi:10.1080/17477160600586747

8. Monteiro CA, Conde WL, Lu B, Popkin BM. Obesity and inequities in health in the developing world. Int J Obes Relat Metab Disord (2004) 28:1181-6. doi:10.1038/sj.ijo.0802716

9. Aguilera CM, Olza J, Gil A. Genetic susceptibility to obesity and metabolic syndrome in childhood. Nutr Hosp (2013) 28:44-55. doi:10.3305/nh.2013.28. sup5.6917

10. Serra Majem L, Ribas Barba L, Aranceta Bartrina J, Pérez Rodrigo C, Saavedra Santana P, Peña Quintana L. [Childhood and adolescent obesity in Spain. Results of the enKid study (1998-2000)]. Med Clin (Barc) (2003) 121:725-32. doi:10.1016/S0025-7753(03)74077-9

11. Flegal KM, Troiano RP, Pamuk ER, Kuczmarski RJ, Campbell SM. The influence of smoking cessation on the prevalence of overweight in the United States. N Engl J Med (1995) 333:1165-70. doi:10.1056/NEJM199511023331801

12. Bautista-Castaño I, Sangil-Monroy M, Serra-Majem L; Comité de Nutrición y Obesidad Infantil de la Sociedad Española de Nutrición Comunitaria. [Knowledge and gaps on the role of nutrition and physical activity on the onset of childhood obesity]. Med Clin (Barc) (2004) 123:782-93.

13. Freedman DS, Dietz WH, Tang R, Mensah GA, Bond MG, Urbina EM, et al. The relation of obesity throughout life to carotid intima-media thickness in adulthood: the Bogalusa Heart Study. Int J Obes Relat Metab Disord (2004) 28:159-66. doi:10.1038/sj.ijo.0802515

14. Lauer RM, Lee J, Clarke WR. Factors affecting the relationship between childhood and adult cholesterol levels: the Muscatine Study. Pediatrics (1988) 82:309-18.

15. Bremer AA, Mietus-Snyder M, Lustig RH. Toward a unifying hypothesis of metabolic syndrome. Pediatrics (2012) 129:557-70. doi:10.1542/peds.20112912

16. Shu CJ, Benoist C, Mathis D. The immune system's involvement in obesitydriven type 2 diabetes. Semin Immunol (2012) 24:436-42. doi:10.1016/j.smim. 2012.12.001

17. Falagas ME, Kompoti M. Obesity and infection. Lancet Infect Dis (2006) 6:438-46. doi:10.1016/S1473-3099(06)70523-0

18. Milner JJ, Beck MA. The impact of obesity on the immune response to infection. Proc Nutr Soc (2012) 71:298-306. doi:10.1017/S0029665112000158

19. Gregor MF, Hotamisligil GS. Inflammatory mechanisms in obesity. Annu Rev Immunol (2011) 29:415-45. doi:10.1146/annurev-immunol-031210-101322

20. Hotamisligil GS, Shargill NS, Spiegelman BM. Adipose expression of tumor necrosis factor-alpha: direct role in obesity-linked insulin resistance. Science (1993) 259:87-91. doi:10.1126/science.7678183

21. Pradhan AD, Manson JE, Rifai N, Buring JE, Ridker PM. C-reactive protein, interleukin 6, and risk of developing type 2 diabetes mellitus. JAMA (2001) 286:327-34. doi:10.1001/jama.286.3.327

22. Lumeng CN, Bodzin JL, Saltiel AR. Obesity induces a phenotypic switch in adipose tissue macrophage polarization. J Clin Invest (2007) 117:175-84. doi:10.1172/JCI29881

23. Lumeng CN, Deyoung SM, Bodzin JL, Saltiel AR. Increased inflammatory properties of adipose tissue macrophages recruited during diet-induced obesity. Diabetes (2007) 56:16-23. doi:10.2337/db06-1076

24. Osborn O, Olefsky JM. The cellular and signaling networks linking the immune system and metabolism in disease. Nat Med (2012) 18:363-74. doi:10.1038/nm.2627

25. Olefsky JM, Glass CK. Macrophages, inflammation, and insulin resistance. Annu Rev Physiol (2010) 72:219-46. doi:10.1146/annurev-physiol-021909135846 
26. Patsouris D, Li PP, Thapar D, Chapman J, Olefsky JM, Neels JG. Ablation of CD11c-positive cells normalizes insulin sensitivity in obese insulin resistant animals. Cell Metab (2008) 8:301-9. doi:10.1016/j.cmet.2008.08.015

27. Wellen KE, Hotamisligil GS. Inflammation, stress, and diabetes. J Clin Invest (2005) 115:1111-9. doi:10.1172/JCI25102

28. Huh JY, Park YJ, Ham M, Kim JB. Crosstalk between adipocytes and immune cells in adipose tissue inflammation and metabolic dysregulation in obesity. Mol Cells (2014) 37:365-71. doi:10.14348/molcells.2014.0074

29. Rocha VZ, Folco EJ, Sukhova G, Shimizu K, Gotsman I, Vernon AH, et al. Interferon-gamma, a Thl cytokine, regulates fat inflammation: a role for adaptive immunity in obesity. Circ Res (2008) 103:467-76. doi:10.1161/ CIRCRESAHA.108.177105

30. O’Rourke RW, White AE, Metcalf MD, Winters BR, Diggs BS, Zhu X. Systemic inflammation and insulin sensitivity in obese IFN- $\gamma$ knockout mice. Metabolism (2012) 61:1152-61. doi:10.1016/j.metabol.2012.01.018

31. DeFuria J, Belkina AC, Jagannathan-Bogdan M, Snyder-Cappione J, Carr JD, Nersesova YR, et al. B cells promote inflammation in obesity and type 2 diabetes through regulation of T-cell function and an inflammatory cytokine profile. Proc Natl Acad Sci USA (2013) 110:5133-8. doi:10.1073/pnas.1215840110

32. Feuerer M, Herrero L, Cipolletta D, Naaz A, Wong J, Nayer A, et al. Lean, but not obese, fat is enriched for a unique population of regulatory $\mathrm{T}$ cells that affect metabolic parameters. Nat Med (2009) 15:930-9. doi:10.1038/nm.2002

33. Han JM, Patterson SJ, Speck M, Ehses JA, Levings MK. Insulin inhibits IL-10mediated regulatory T cell function: implications for obesity. J Immunol (2014) 192:623-9. doi:10.4049/jimmunol.1302181

34. Winer S, Paltser G, Chan Y, Tsui H, Engleman E, Winer D. Obesity predisposes to Th17 bias. Eur J Immunol (2009) 39:2629-35. doi:10.1002/eji. 200838893

35. Sumarac-Dumanovic M, Stevanovic D, Ljubic A, Jorga J, Simic M, Stamenkovic-Pejkovic D, et al. Increased activity of interleukin-23/interleukin17 proinflammatory axis in obese women. Int J Obes (Lond) (2009) 33:151-6. doi:10.1038/ijo.2008.216

36. Jagannathan-Bogdan M, McDonnell ME, Shin H, Rehman Q, Hasturk H, Apovian CM, et al. Elevated proinflammatory cytokine production by a skewed $\mathrm{T}$ cell compartment requires monocytes and promotes inflammation in type 2 diabetes. J Immunol (2011) 186:1162-72. doi:10.4049/jimmunol. 1002615

37. Zúñiga LA, Shen WJ, Joyce-Shaikh B, Pyatnova EA, Richards AG, Thom C. IL17 regulates adipogenesis, glucose homeostasis, and obesity. J Immunol (2010) 185:6947-59. doi:10.4049/jimmunol.1001269

38. Pini M, Fantuzzi G. Enhanced production of IL-17A during zymosaninduced peritonitis in obese mice. J Leukoc Biol (2010) 87:51-8. doi:10.1189/ jlb.0309188

39. Ahmed M, Gaffen SL. IL-17 in obesity and adipogenesis. Cytokine Growth Factor Rev (2010) 21:449-53. doi:10.1016/j.cytogfr.2010.10.005

40. Erbel C, Akhavanpoor M, Okuyucu D, Wangler S, Dietz A, Zhao L, et al. IL17A influences essential functions of the monocyte/macrophage lineage and is involved in advanced murine and human atherosclerosis. J Immunol (2014) 193:4344-55. doi:10.4049/jimmunol.1400181

41. Rausch ME, Weisberg S, Vardhana P, Tortoriello DV. Obesity in C57BL/6J mice is characterized by adipose tissue hypoxia and cytotoxic T-cell infiltration. Int J Obes (Lond) (2008) 32:451-63. doi:10.1038/sj.ijo.0803744

42. Nishimura S, Manabe I, Nagasaki M, Eto K, Yamashita H, Ohsugi M, et al. $\mathrm{CD} 8+$ effector $\mathrm{T}$ cells contribute to macrophage recruitment and adipose tissue inflammation in obesity. Nat Med (2009) 15:914-20. doi:10.1038/nm.1964

43. Jiang E, Perrard XD, Yang D, Khan IM, Perrard JL, Smith CW, et al. Essential role of CD11a in CD8+ T-cell accumulation and activation in adipose tissue. Arterioscler Thromb Vasc Biol (2014) 34:34-43. doi:10.1161/ATVBAHA. 113.302077

44. Winer DA, Winer S, Shen L, Wadia PP, Yantha J, Paltser G, et al. B cells promote insulin resistance through modulation of $\mathrm{T}$ cells and production of pathogenic IgG antibodies. Nat Med (2011) 17:610-7. doi:10.1038/nm.2353

45. Abeysekara P, Turchi R, O'Neil M. Obesity and children with special healthcare needs: special considerations for a special population. Curr Opin Pediatr (2014) 26:508-15. doi:10.1097/MOP.0000000000000124

46. Del Chirico F, Vernocchi P, Dallapiccola B, Putignani L. Mediterranean diet and health: food effects on gut microbiota and disease control. Int J Mol Sci (2014) 15:11678-99. doi:10.3390/ijms150711678
47. Cao AT, Yao S, Stefka AT, Liu Z, Qin H, Liu H, et al. TLR4 regulates IFN- $\gamma$ and IL-17 production by both thymic and induced Foxp3+ Tregs during intestinal inflammation. J Leukoc Biol (2014) 96:895-905. doi:10.1189/jlb.3A0114056RR

48. Weber A, Zimmermann C, Kieseier BC, Hartung HP, Hofstetter HH. Bacteria and their cell wall components uniformly co-active IL-17 producing thymocytes. Clin Exp Immunol (2014) 178:504-15. doi:10.1111/cei.12414

49. Cosmi L, Liotta F, Maggi E, Romagnani S, Annunziato F. Th17 and non-classic Th1 cells in chronic inflammatory disorders: two sides of the same coin. Int Arch Allergy Immunol (2014) 164:171-7. doi:10.1159/000363502

50. Zeng $\mathrm{H}$, Chi $\mathrm{H}$. The interplay between regulatory $\mathrm{T}$ cells and metabolism in immune regulation. Oncoimmunology (2013) 2:e26586. doi:10.4161/onci. 26586

51. Iyer SS, Cheng G. Role of interleukin 10 transcriptional regulation in inflammation and autoimmune disease. Crit Rev Immunol (2012) 32:23-63. doi:10. 1615/CritRevImmunol.v32.i1.30

52. Pereira S, Teixeira L, Aguilar E, Oliveira M, Savassi-Rocha A, Pelaez JN, et al. Modulation of adipose tissue inflammation by FOXP3+ Treg cell, IL-10, and TGF- $\beta$ in metabolically healthy class III obese individuals. Nutrition (2014) 30:784-90. doi:10.1016/j.nut.2013.11.023

53. Cole TJ, Lobstein T. Extended international (IOTF) body mass index cutoffs for thinness, overweight and obesity. Pediatr Obes (2012) 7:284-94. doi:10.1111/j.2047-6310.2012.00064.x

54. O'Keefe JH, Gheewala NM, O'Keefe JO. Dietary strategies for improving postprandial glucose, lipids, inflammation, and cardiovascular health. J Am Coll Cardiol (2008) 51:249-55. doi:10.1016/j.jacc.2007.10.016

55. Holt EM, Steffen LM, Moran A, Basu S, Steinberger J, Ross JA, et al. Fruit and vegetable consumption and its relation to markers of inflammation and oxidative stress in adolescents. J Am Diet Assoc (2009) 109(3):414-21. doi:10.1016/j.jada.2008.11.036

56. Casas R, Sacanella E, Estruch R. The immune protective effect of the Mediterranean diet against chronic low-grade inflammatory diseases. Endocr Metab Immune Disord Drug Targets (2014) 14:245-54. doi:10.2174/ 1871530314666140922153350

57. Bonaccio M, Di Castelnuovo A, Bonanni A, Costanzo S, De Lucia F, Persichillo $\mathrm{M}$, et al. Decline of the Mediterranean diet at a time of economic crisis. Results from the Moli-Sani study. Nutr Metab Cardiovasc Dis (2014) 24:853-60. doi:10.1016/j.numecd.2014.02.014

58. Lim GB. Risk factors: mechanistic insights into the cardiovascular benefits of a Mediterranean diet. Nat Rev Cardiol (2014) 11:433. doi:10.1038/nrcardio. 2014.92

59. Knoops KT, de Groot LC, Kromhout D, Perrin AE, Moreiras-Varela O, Menotti A, et al. Mediterranean diet, lifestyle factors, and 10-year mortality in elderly European men and women: the HALE project. JAMA (2004) 292:1433-9. doi:10.1001/jama.292.12.1433

60. Vieira VJ, Valentine RJ, Wilund KR, Antao N, Baynard T, Woods JA. Effects of exercise and low-fat diet on adipose tissue inflammation and metabolic complications in obese mice. Am J Physiol Endocrinol Metab (2009) 296:E1164-71. doi:10.1152/ajpendo.00054.2009

61. Gleeson M, Bishop NC, Stensel DJ, Lindley MR, Mastana SS, Nimmo MA. The anti-inflammatory effects of exercise: mechanisms and implications for the prevention and treatment of disease. Nat Rev Immunol (2011) 11:607-11. doi:10.1038/nri3041

62. Miglio C, Peluso I, Raguzzini A, Villaño DV, Cesqui E, Catasta G, et al. Antioxidant and antiinflammatory response following high-fat meal consumption in overweight subjects. Eur J Nutr (2012) 52:1107-14. doi:10.1007/s00394-0120420-7

63. Calder PC, Ahluwalia N, Brouns F, Buetler T, Clement K, Cunningham K, et al. Dietary factors and low-grade inflammation in relation to overweight and obesity. Br J Nutr (2011) 106:S5-78. doi:10.1017/S0007114511005460

64. Korhonen R, Kosonen O, Hamalainen M, Moilanen E. Nitric oxide-releasing compounds inhibit the production of interleukin-2, -4 and -10 in activated human lymphocytes. Basic Clin Pharmacol Toxicol (2008) 103:322-8. doi:10.1111/j.1742-7843.2008.00275.x

65. Cani PD, Bibiloni R, Knauf C, Waget A, Neyrinck AM, Delzenne NM, et al. Changes in gut microbiota control metabolic endotoxemia-induced inflammation in high-fat diet-induced obesity and diabetes in mice. Diabetes (2008) 57:1470-81. doi:10.2337/db07-1403 
66. Rigoulet M, Yoboue ED, Devin A. Mitochondrial ROS generation and its regulation: mechanisms involved in $\mathrm{H}(2) \mathrm{O}(2)$ signaling. Antioxid Redox Signal (2011) 14:459-68. doi:10.1089/ars.2010.3363

67. Leloup C, Casteilla L, Carrière A, Galinier A, Benani A, Carneiro L, et al. Balancing mitochondrial redox signaling: a key point in metabolic regulation. Antioxid Redox Signal (2011) 14:519-30. doi:10.1089/ars.2010.3424

68. Bisbal C, Lambert K, Avignon A. Antioxidants and glucose metabolism disorders. Curr Opin Clin Nutr Metab Care (2010) 13:439-46. doi:10.1097/MCO. 0b013e32833a5559

69. Hulsmans M, Van Dooren E, Holvoet P. Mitochondrial reactive oxygen species and risk of atherosclerosis. Curr Atheroscler Rep (2012) 14:264-76. doi:10.1007/s11883-012-0237-0

70. Grimsrud PA, Picklo MJ, Griffin TJ, Bernlohr DA. Carbonylation of adipose proteins in obesity and insulin resistance: identification of adipocyte fatty acidbinding protein as a cellular target of 4-hydroxynonenal. Mol Cell Proteomics (2007) 6:624-37. doi:10.1074/mcp.M600120-MCP200

71. Atilgan D, Parlaktas BS, Uluocak N, Erdemir F, Kilic S, Erkorkmaz U, et al. Weight loss and melatonin reduce obesity-induced oxidative damage in rat testis. Adv Urol (2013) 2013:836121. doi:10.1155/2013/836121

72. Keaney JF, Larson MG, Vasan RS, Wilson PW, Lipinska I, Corey D, et al. Obesity and systemic oxidative stress: clinical correlates of oxidative stress in the Framingham Study. Arterioscler Thromb Vasc Biol (2003) 23:434-9. doi:10.1161/01.ATV.0000058402.34138.11

73. Morrow JD. The isoprostanes: their quantification as an index of oxidant stress status in vivo. Drug Metab Rev (2000) 32:377-85. doi:10.1081/DMR100102340

74. Daví G, Guagnano MT, Ciabattoni G, Basili S, Falco A, Marinopiccoli M, et al. Platelet activation in obese women: role of inflammation and oxidant stress. JAMA (2002) 288:2008-14. doi:10.1001/jama.288.16.2008

75. Lee H, Lee YJ, Choi H, Ko EH, Kim JW. Reactive oxygen species facilitate adipocyte differentiation by accelerating mitotic clonal expansion. J Biol Chem (2009) 284:10601-9. doi:10.1074/jbc.M808742200

76. Fleming I, MacKenzie SJ, Vernon RG, Anderson NG, Houslay MD, Kilgour E. Protein kinase $\mathrm{C}$ isoforms play differential roles in the regulation of adipocyte differentiation. Biochem J (1998) 333:719-27.

77. Bansode RR, Huang W, Roy SK, Mehta M, Mehta KD. Protein kinase C deficiency increases fatty acid oxidation and reduces fat storage. J Biol Chem (2008) 283:231-6. doi:10.1074/jbc.M707268200

78. Huang W, Bansode R, Mehta M, Mehta KD. Loss of protein kinase Cbeta function protects mice against diet-induced obesity and development of hepatic steatosis and insulin resistance. Hepatology (2009) 49:1525-36. doi:10.1002/ hep. 22815

79. Stowe DF, Camara AK. Mitochondrial reactive oxygen species production in excitable cells: modulators of mitochondrial and cell function. Antioxid Redox Signal (2009) 11:1373-414. doi:10.1089/ARS.2008.2331

80. Anderson EJ, Lustig ME, Boyle KE, Woodlief TL, Kane DA, Lin CT, et al. Mitochondrial $\mathrm{H} 2 \mathrm{O} 2$ emission and cellular redox state link excess fat intake to insulin resistance in both rodents and humans. J Clin Invest (2009) 119:573-81. doi:10.1172/JCI37048

81. Kusminski CM, Holland WL, Sun K, Park J, Spurgin SB, Lin Y, et al. MitoNEETdriven alterations in adipocyte mitochondrial activity reveal a crucial adaptive process that preserves insulin sensitivity in obesity. Nat Med (2012) 18:1539-49. doi:10.1038/nm.2899

82. Loffredo L, Martino F, Carnevale R, Pignatelli P, Catasca E, Perri L, et al. Obesity and hypercholesterolemia are associated with NOX2 generated oxidative stress and arterial dysfunction. J Pediatr (2012) 161:1004-9. doi:10.1016/j. jpeds.2012.05.042

83. Furukawa S, Fujita T, Shimabukuro M, Iwaki M, Yamada Y, Nakajima Y, et al. Increased oxidative stress in obesity and its impact on metabolic syndrome. $J$ Clin Invest (2004) 114:1752-61. doi:10.1172/JCI21625

84. Bastard JP, Piéroni L, Hainque B. Relationship between plasma plasminogen activator inhibitor 1 and insulin resistance. Diabetes Metab Res Rev (2000) 16:192-201. doi:10.1002/1520-7560(200005/06)16:3<192::AID-DMRR114> 3.0.CO;2-G

85. Yamauchi T, Kamon J, Waki H, Terauchi Y, Kubota N, Hara K, et al. The fatderived hormone adiponectin reverses insulin resistance associated with both lipoatrophy and obesity. Nat Med (2001) 7:941-6. doi:10.1038/90984
86. Okamoto Y, Kihara S, Ouchi N, Nishida M, Arita Y, Kumada M, et al. Adiponectin reduces atherosclerosis in apolipoprotein E-deficient mice. Circulation (2002) 106:2767-70. doi:10.1161/01.CIR.0000042707.50032.19

87. Bonnefont-Rousselot D. Obesity and oxidative stress: potential roles of melatonin as antioxidant and metabolic regulator. Endocr Metab Immune Disord Drug Targets (2014) 14:159-68. doi:10.2174/1871530314666140604151452

88. Vazzana N, Guagnano MT, Cuccurullo C, Ferrante E, Lattanzio S, Liani R, et al. Endogenous secretory RAGE in obese women: association with platelet activation and oxidative stress. J Clin Endocrinol Metab (2012) 97:E1726-30. doi:10.1210/jc.2012-1473

89. Vitale E, Jirillo E, Magrone T. Correlations between the youth healthy eating index, body mass index and the salivary nitric oxide concentration in overweight/obese children. Endocr Metab Immune Disord Drug Targets (2014) 14:93-101. doi:10.2174/1871530314666140307095630

90. Guenther PM, Reedy J, Krebs-Smith SM. Development of the healthy eating index 2005. J Am Diet Assoc (2008) 108:1896-901. doi:10.1016/j.jada.2008. 08.016

91. Ruiz JR, Ortega FB, Martinez-Gomes D, Labayen I, Moreno LA, De Bourdeaudhuij I, et al. Objectively measured physical activity and sedentary time in European adolescents. Am J Epidemiol (2011) 174:173-84. doi:10.1093/aje/ kwr068

92. Jimenez-Pavon D, Kelly J, Reilly JJ. Associations between objectively measured habitual physical activity and adiposity in children and adolescents: systematic review. Int J Pediatr Obes (2010) 5:3-18. doi:10.3109/17477160903067601

93. Ortega FB, Artero EG, Ruiz JR, Espana-Romero V, Jimenez-Pavon D, VicenteRodriguez G, et al. Physical fitness levels among European adolescents: the HELENA study. BrJSports Med (2011) 45:20-9. doi:10.1136/bjsm.2009.062679

94. Herman KM, Sabiston CM, Mathieu ME, Tremblay A, Paradis G. Sedentary behavior in a cohort of 8 - to 10 -year-old children at elevated risk of obesity. Prev Med (2014) 60:115-20. doi:10.1016/j.ypmed.2013.12.029

95. Swinburn BA, Sacks G, Hall KD, McPherson K, Finegood DT, Moodie ML, et al. The global obesity pandemic: shaped by global drivers and local environments. Lancet (2011) 378:804-14. doi:10.1016/S0140-6736(11)60813-1

96. Collison KS, Zaidi MZ, Subhani SN, Al-Rubeaan K, Shoukri M, Al-Mohanna FA. Sugar-sweetened carbonated beverage consumption correlates with BMI, waist circumference, and poor dietary choices in school children. BMC Public Health (2010) 10:234. doi:10.1186/1471-2458-10-234

97. Choi JW. Enhanced nitric oxide production is closely associated with serum lipid concentrations in adolescents. Clin Chim Acta (2004) 347:151-6. doi:10. 1016/j.cccn.2004.04.024

98. Ghasemi A, Zahediasl S, Azizi F. Nitric oxide and clustering of metabolic syndrome components in pediatrics. Eur J Epidemiol (2010) 25:45-53. doi:10. 1007/s10654-009-9382-3

99. Codoñer-Franch P, Tavárez-Alonso S, Estal RM, Megías-Vericat J, TortajadaGirbés M, Alonso-Iglesias E. Nitric oxide production is increased in severely obese children and related to markers of oxidative stress and inflammation. Atherosclerosis (2011) 215:475-80. doi:10.1016/j.atherosclerosis.2010.12.035

100. Ghasemi A, Zahediasl S, Azizi F. Elevated nitric oxide metabolites are associated with obesity in women. Arch Iran Med (2013) 16:521-5. doi:013169/AIM.008

101. Fogarty AW, Glancy C, Jones S, Lewis SA, McKeever TM, Britton JR. A prospective study of weight change and systemic inflammation over 9 y. Am J Clin Nutr (2008) 87:30-5.

102. Geissmann F, Manz MG, Jung S, Sieweke MH, Merad M, Ley K. Development of monocytes, macrophages, and dendritic cells. Science (2011) 327:656-61. doi:10.1126/science.1178331

103. Heilbronn LK, Campbell LV. Adipose tissue macrophages, low grade inflammation and insulin resistance in human obesity. Curr Pharm Des (2008) 14:1225-30. doi:10.2174/138161208784246153

104. Edwards JP, Zhang X, Frauwirth KA, Mosser DM. Biochemical and functional characterization of three activated macrophage populations. J Leukoc Biol (2008) 80:1298-307. doi:10.1189/jlb.0406249

105. Gruber HJ, Mayer C, Mangge H, Fauler G, Grandits N, Wilders-Truschnig M. Obesity reduces the bioavailability of nitric oxide in juveniles. Int J Obes (2008) 32:826-31. doi:10.1038/sj.ijo.0803795

106. Jensen ME, Collins CE, Gibson PG, Wood LG. The obesity phenotype in children with asthma. Paediatr Respir Rev (2011) 12:152-9. doi:10.1016/j.prrv 2011.01.009 
107. Lugogo NL, Kraft M, Dixon AE. Does obesity produce a distinct asthma phenotype? J App Physiol (1985) (2010) 108:729-34. doi:10.1152/japplphysiol. 00845.2009

108. van Veen IH, Ten Brinke A, Sterk PJ, Rabe KF, Bel EH. Airway inflammation in obese and nonobese patients with difficult-to-treat asthma. Allergy (2008) 63:570-4. doi:10.1111/j.1398-9995.2007.01597.x

109. Eder W, Ege MJ, von Mutius E. The asthma epidemic. N Engl J Med (2006) 355:2226-35. doi:10.1056/NEJMra054308

110. Campfield LA, Smith FJ, Guisez Y, Devos R, Burn P. Recombinant mouse OB protein: evidence for a peripheral signal linking adiposity and central neural networks. Science (1995) 269:546-9. doi:10.1126/science.7624778

111. Procaccini C, Jirillo E, Matarese G. Leptin as an immunomodulator. Mol Aspects Med (2012) 33:35-45. doi:10.1016/j.mam.2011.10.012

112. Kumada M, Kihara S, Ouchi N, Kobayashi H, Okamoto Y, Ohashi K, et al. Adiponectin specifically increased tissue inhibitor of metalloproteinase-1 through interleukin-10 expression in human macrophages. Circulation (2004) 109:2046-9. doi:10.1161/01.CIR.0000127953.98131.ED

113. Bokarewa M, Nagaev I, Dahlberg L, Smith U, Tarkowski A. Resistin, an adipokine with potent proinflammatory properties. J Immunol (2005) 174:5789-95. doi:10.4049/jimmunol.174.9.5789

114. Stastny J, Bienertova-Vasku J, Vasku A. Visfatin and its role in obesity development. Diabetes Metab Syndr (2012) 6:120-4. doi:10.1016/j.dsx.2012.08.011

115. Hug C, Lodish HF. Medicine. Visfatin: a new adipokine. Science (2005) 307:366-7. doi:10.1126/science.1106933

116. Bidulescu A, Liu J, Hickson DA, Hairston KG, Fox ER, Arnett DK, et al. Gender differences in the association of visceral and subcutaneous adiposity with adiponectin in African Americans: the Jackson Heart Study. BMC Cardiovasc Disord (2013) 13:9. doi:10.1186/1471-2261-13-9

117. Magrone T, Simone M, Mappa L, Tesse R, Giordano P, Altamura M, et al. Characterization of the immune inflammatory profile in obese asthmatic children. Endocr Metab Immune Disord Drug Targets (2014) 14:187-95. doi:10.2174/1871530314666140526095211

118. Pedersen SE, Hurd SS, Lemanske RF Jr., Becker A, Zar HJ, Sly PD, et al. Global strategy for the diagnosis and management of asthma in children 5 years and younger. Pediatr Pulmonol (2011) 46:1-17. doi:10.1002/ ppul.21321

119. Youssef DM, Elbehidy RM, Shokry DM, Elbehidy EM. The influence of leptin on Th1/Th2 balance in obese children with asthma. J Bras Pneumol (2013) 39:562-8. doi:10.1590/S1806-37132013000500006

120. El-Wakkad A, Hassan Nel-M, Sibaii H, El-Zayat SR. Proinflammatory, antiinflammatory cytokines and adipokines in students with central obesity. Cytokine (2013) 61:682-7. doi:10.1016/j.cyto.2012.11.010

121. Kabat AM, Srinivasan N, Maloy KJ. Modulation of immune development and function by intestinal microbiota. Trends Immunol (2014) 35:507-17. doi:10.1016/j.it.2014.07.010

122. Ivanov II, Atarashi K, Manel N, Brodie EL, Shima T, Karaoz U, et al. Induction of intestinal Th17 cells by segmented filamentous bacteria. Cell (2009) 139:485-98. doi:10.1016/j.cell.2009.09.033

123. Magrone T, Jirillo E. The interplay between the gut immune system and microbiota in health and disease: nutraceutical intervention for restoring intestinal homeostasis. Curr Pharm Des (2013) 19:1329-42. doi:10.2174/ 138161213804805793

124. Mesquita DN, Barbieri MA, Goldani HA, Cardoso VC, Goldani MZ, Kac $\mathrm{G}$, et al. Cesarean section is associated with increased peripheral and central adiposity in young adulthood: cohort study. PLoS One (2013) 8:e66827. doi:10.1371/journal.pone.0066827

125. Gibbs BG, Forste R. Socioeconomic status, infant feeding practices and early childhood obesity. Pediatr Obes (2014) 9:135-46. doi:10.1111/j.2047-6310. 2013.00155.x

126. Cho I, Yamanishi S, Cox L, Methé BA, Zavadil J, Li K. Antibiotics in early life alter the murine colonic microbiome and adiposity. Nature (2012) 488:621-6. doi:10.1038/nature 11400

127. Riley LW, Raphael E, Faerstein E. Obesity in the United States - dysbiosis from exposure to low-dose antibiotics? Front Public Health (2013) 1:69. doi:10.3389/fpubh.2013.00069

128. Hooper LV, Littman DR, Macpherson AJ. Interactions between the microbiota and the immune system. Science (2012) 336:1268-73. doi:10.1126/science. 1223490
129. Spear BA, Barlow SE, Ervin C, Ludwig DS, Saelens BE, Schetzina KE, et al. Recommendations for treatment of child and adolescent overweight and obesity. Pediatrics (2007) 120:S254-88. doi:10.1542/peds.2007-2329F

130. Wang SP, Laurin N, Himms-Hagen J, Rudnicki MA, Levy E, Robert MF. The adipose tissue phenotype of hormone-sensitive lipase deficiency in mice. Obes Res (2001) 9:119-28. doi:10.1038/oby.2001.15

131. Davis MM, Gance-Cleveland B, Hassink S, Johnson R, Paradis G, Resnicow K. Recommendations for prevention of childhood obesity. Pediatrics (2007) 120:S229-53. doi:10.1542/peds.2007-2329E

132. Kar SS, Dube R, Kar SS. Childhood obesity-an insight into preventive strategies. Avicenna J Med (2014) 4:88-93. doi:10.4103/2231-0770.140653

133. Cani PD, Possemiers S, Van de Wiele T, Guiot Y, Everard A, Rottier O, et al. Changes in gut microbiota control inflammation in obese mice through a mechanism involving GLP-2-driven improvement of gut permeability. Gut (2009) 58:1091-103. doi:10.1136/gut.2008.165886

134. Fan JG, Xu ZJ, Wang GL. Effect of lactulose on establishment of a rat non-alcoholic steatohepatitis model. World J Gastroenterol (2005) 11:5053-6. doi:10.3748/wjg.v11.i32.5053

135. Holscher HD, Faust KL, Czerkies LA, Litov R, Ziegler EE, Lessin H, et al. Effects of prebiotic-containing infant formula on gastrointestinal tolerance and fecal microbiota in a randomized controlled trial. JPEN J Parenter Enteral Nutr (2012) 36:95S-105S. doi:10.1177/0148607111430087

136. Daubioul CA, Horsmans Y, Lambert P, Danse E, Delzenne NM. Effect of oligofructose on glucose and lipid metabolism in patients with nonalcoholic stateohepatitis: results of pilot study. Eur J Clin Nutr (2005) 59:723-6. doi:10.1038/sj.ejcn.1602127

137. Yang M, Gong S, Ye SQ, Lyman B, Geng L, Chen P, et al. Non-alcoholic Fatty liver disease in children: focus on nutritional interventions. Nutrients (2014) 6:4691-705. doi:10.3390/nu6114691

138. Angelakis E, Armougom F, Million M, Raoult D. The relationship between gut microbiota and weight gain in humans. Future Microbiol (2012) 7:91-109. doi: $10.2217 / \mathrm{fmb} .11 .142$

139. Santacruz A, Collado MC, García-Valdés L, Segura MT, Martín-Lagos JA, Anjos $\mathrm{T}$, et al. Gut microbiota composition is associated with body weight, weight gain and biochemical parameters in pregnant women. Br J Nutr (2010) 104:83-92. doi:10.1017/S0007114510000176

140. Walker AW, Ince J, Duncan SH, Webster LM, Holtrop G, Ze X, et al. Dominant and diet-responsive groups of bacteria within the human colonic microbiota. ISME J (2011) 5:220-30. doi:10.1038/ismej.2010.118

141. Kadooka Y, Sato M, Imaizumi K, Ogawa A, Ikuyama K, Akai Y, et al. Regulation of abdominal adiposity by probiotics (Lactobacillus gasseri SBT2055) in adults with obese tendencies in a randomized controlled trial. Eur J Clin Nutr (2010) 64:636-43. doi:10.1038/ejcn.2010.19

142. Borody TJ, Paramsothy S, Agrawal G. Fecal microbiota transplantation: indications, methods, evidence, and future directions. Curr Gastroenterol Rep (2013) 15:337. doi:10.1007/s11894-013-0337-1

143. Vrieze A, Van Nood E, Holleman F, Salojärvi J, Kootte RS, Bartelsman JF, et al. Transfer of intestinal microbiota from lean donors increases insulin sensitivity in individuals with metabolic syndrome. Gastroenterology (2012) 143: 913-6.e7. doi:10.1053/j.gastro.2012.06.031

144. Xu P, Li M, Zhang J, Zhang T. Correlation of intestinal microbiota with overweight and obesity in Kazakh school children. BMC Microbiol (2012) 12:283. doi:10.1186/1471-2180-12-283

145. Karlsson CL, Onnerfält J, Xu J, Molin G, Ahrné S, Thorngren-Jerneck K. The microbiota of the gut in preschool children with normal and excessive body weight. Obesity (Silver Spring) (2012) 20:2257-61. doi:10.1038/oby.2012.110

146. Everard A, Belzer C, Geurts L, Ouwerkerk JP, Druart C, Bindels LB, et al. Cross-talk between Akkermansia muciniphila and intestinal epithelium controls diet-induced obesity. Proc Natl Acad Sci USA (2013) 110:9066-71. doi:10.1073/pnas.1219451110

147. Luoto R, Kalliomäki M, Laitinen K, Isolauri E. The impact of perinatal probiotic intervention on the development of overweight and obesity: followup study from birth to 10 years. Int J Obes (Lond) (2010) 34:1531-7. doi:10.1038/ijo.2010.50

148. Laitinen K, Poussa T, Isolauri E; Nutrition, Allergy, Mucosal Immunology and Intestinal Microbiota Group. Probiotics and dietary counselling contribute to glucose regulation during and after pregnancy: a randomised controlled trial. Br J Nutr (2009) 101:1679-87. doi:10.1017/S0007114508111461 
149. Luoto R, Laitinen K, Nermes M, Isolauri E. Impact of maternal probioticsupplemented dietary counselling on pregnancy outcome and prenatal and postnatal growth: a double-blind, placebo-controlled study. Br J Nutr (2010) 103:1792-9. doi:10.1017/S0007114509993898

150. Cabrera-Rubio R, Collado MC, Laitinen K, Salminen S, Isolauri E, Mira A. The human milk microbiome changes over lactation and is shaped by maternal weight and mode of delivery. Am J Clin Nutr (2012) 96:544-51. doi:10.3945/ajen.112.037382

151. Jirillo E, Jirillo F, Magrone T. Healthy effects exerted by prebiotics, probiotics, and symbiotics with special reference to their impact on the immune system. Int J Vitam Nutr Res (2012) 82:200-88. doi:10.1024/0300-9831/a000112

152. Kelishadi R, Farajian S, Safavi M, Mirlohi M, Hashemipour M. A randomized triple-masked controlled trial on the effects of synbiotics on inflammation markers in overweight children. J Pediatr (Rio J) (2014) 90:161-8. doi:10.1016/j.jped.2013.07.003

153. Fekete K, Marosvölgyi T, Jakobik V, Decsi T. Methods of assessment of n-3 long-chain polyunsaturated fatty acid status in humans: a systematic review. Am J Clin Nutr (2009) 89:2070S-84S. doi:10.3945/ajcn.2009.27230I

154. Wang H, Storlien LH, Huang XF. Effects of dietary fat types on body fatness, leptin, and ARC leptin receptor, NPY, and AgRP mRNA expression. Am J Physiol Endocrinol Metab (2002) 282:E1352-9. doi:10.1152/ajpendo.00230.2001

155. Kushi L, Giovannucci E. Dietary fat and cancer. Am J Med (2002) 113:63S-70S. doi:10.1016/S0002-9343(01)00994-9

156. Kelley DS, Siegel D, Vemuri M, Mackey BE. Docosahexaenoic acid supplementation improves fasting and postprandial lipid profiles in hypertriglyceridemic men. Am J Clin Nutr (2007) 86:324-33.

157. Adkins Y, Kelley DS. Mechanisms underlying the cardioprotective effects of omega-3 polyunsaturated fatty acids. J Nutr Biochem (2010) 21:781-92. doi:10.1016/j.jnutbio.2009.12.004

158. Ailhaud G, Massiera F, Weill P, Legrand P, Alessandri JM, Guesnet P. Temporal changes in dietary fats: role of n-6 polyunsaturated fatty acids in excessive adipose tissue development and relationship to obesity. Prog Lipid Res (2006) 45:203-36. doi:10.1016/j.plipres.2006.01.003

159. Massiera F, Saint-Marc P, Seydoux J, Murata T, Kobayashi T, Narumiya $\mathrm{S}$, et al. Arachidonic acid and prostacyclin signaling promote adipose tissue development: a human health concern? J Lipid Res (2003) 44:271-9. doi:10.1194/jlr.M200346-JLR200

160. Azain MJ. Role of fatty acids in adipocyte growth and development. J Anim Sci (2004) 82:916-24.

161. Madsen L, Petersen RK, Kristiansen K. Regulation of adipocyte differentiation and function by polyunsaturated fatty acids. Biochim Biophys Acta (2005) 1740:266-86. doi:10.1016/j.bbadis.2005.03.001

162. Flachs P, Rossmeisl M, Bryhn M, Kopecky J. Cellular and molecular effects of n-3 polyunsaturated fatty acids on adipose tissue biology and metabolism. Clin Sci (Lond) (2009) 116:1-16. doi:10.1042/CS20070456

163. Hauner H, Brunner S, Amann-Gassner U. The role of dietary fatty acids for early human adipose tissue growth. Am J Clin Nutr (2013) 98:549S-55S. doi:10.3945/ajcn.112.040733

164. Mejía-Barradas CM, Del-Río-Navarro BE, Domínguez-López A, CamposRodríguez R, Martínez-Godínez MD, Rojas-Hernández S, et al. The consumption of $n-3$ polyunsaturated fatty acids differentially modulates gene expression of peroxisome proliferator-activated receptor alpha and gamma and hypoxiainducible factor 1 alpha in subcutaneous adipose tissue of obese adolescents. Endocrine (2014) 45:98-105. doi:10.1007/s12020-013-9941-y

165. Magrone T, Kumazawa Y, Jirillo E. Polyphenol-mediated beneficial effects in healthy status and disease with special references to immune-based mechanisms. In: Watson R, Preedy V, Zibaldi S, editors. Polyphenols in Human Health and Disease. Vol. 1. Oxford: Elsevier (2014). p. 467-79.

166. Artero A, Artero A, Tarín JJ, Cano A. The impact of moderate wine consumption on health. Maturitas (2015) 80(1):3-13. doi:10.1016/j.maturitas.2014.09.007

167. Ferrières J. The French paradox: lessons for other countries. Heart (2004) 90:107-11. doi:10.1136/heart.90.1.107

168. Renaud S, de Lorgeril M. Wine, alcohol, platelets, and the French paradox for coronary heart disease. Lancet (1992) 339:1523-6. doi:10.1016/0140-6736(92) 91277-F

169. Franco JG, Lisboa PC, Lima NS, Amaral TA, Peixoto-Silva N, Resende AC, et al. Resveratrol attenuates oxidative stress and prevents steatosis and hypertension in obese rats programmed by early weaning. J Nutr Biochem (2013) 24:960-6. doi:10.1016/j.jnutbio.2012.06.019
170. Park HS, Kim SH, Kim YS, Ryu SY, Hwang JT, Yang HJ, et al. Luteolin inhibits adipogenic differentiation by regulating PPARgamma activation. Biofactors (2009) 35:373-9. doi:10.1002/biof.38

171. Marzulli G, Magrone T, Vonghia L, Kaneko M, Takimoto H, Kumazawa Y. Immunomodulating and anti-allergic effects of Negroamaro and Koshu Vitis vinifera fermented grape marc (FGM). Curr Pharm Des (2014) 20:864-8. doi:10.2174/138161282006140220120640

172. Gu Y, Yu S, Lambert JD. Dietary cocoa ameliorates obesity-related inflammation in high fat-fed mice. Eur J Nutr (2014) 53:149-58. doi:10.1007/s00394013-0510-1

173. Moreno MF, De Laquila R, Okuda MH, Lira FS, de Souza GI, de Souza CT, et al. Metabolic profile response to administration of epigallocatechin-3-gallate in high-fat-fed mice. Diabetol Metab Syndr (2014) 6:84. doi:10.1186/17585996-6-84

174. Mielgo-Ayuso J, Barrenechea L, Alcorta P, Larrarte E, Margareto J, Labayen I. Effects of dietary supplementation with epigallocatechin-3-gallate on weight loss, energy homeostasis, cardiometabolic risk factors and liver function in obese women: randomised, double-blind, placebo-controlled clinical trial. $\mathrm{Br}$ J Nutr (2014) 111:1263-71. doi:10.1017/S0007114513003784

175. Li G, Zhang Y, Mbuagbaw L, Holbrook A, Levine MA, Thabane L. Effect of green tea supplementation on blood pressure among overweight and obese adults: a protocol for a systematic review. BMJ Open (2014) 4:e004971. doi:10.1136/bmjopen-2014-004971

176. Di Renzo L, Rizzo M, Sarlo F, Colica C, Iacopino L, Domino E, et al. Effects of dark chocolate in a population of normal weight obese women: a pilot study. Eur Rev Med Pharmacol Sci (2013) 17:2257-66.

177. Riccioni G, Speranza L, Pesce M, Cusenza S, D’Orazio N, Glade MJ. Novel phytonutrient contributors to antioxidant protection against cardiovascular disease. Nutrition (2012) 28:605-10. doi:10.1016/j.nut.2011.11.028

178. Sari I, Baltaci Y, Bagci C, Davutoglu V, Erel O, Celik H, et al. Effect of pistachio diet on lipid parameters, endothelial function, inflammation, and oxidative status: a prospective study. Nutrition (2010) 26:399-404. doi:10.1016/j.nut.2009. 05.023

179. Korkmaz A, Manchester LC. Reactive nitrogen species; devastating intracellular players and melatonin as a defender. J Exp Integr Med (2011) 1:63-5. doi:10.5455/jeim.270311.ed.003

180. Deng WG, Tang ST, Tseng HP, Wu KK. Melatonin suppresses macrophage cyclooxygenase- 2 and inducible nitric oxide synthase expression by inhibiting p52 acetylation and binding. Blood (2006) 108:518-24. doi:10.1182/blood2005-09-3691

181. Mauriz JL, Collado PS, Veneroso C, Reiter RJ, González-Gallego J. A review of the molecular aspects of melatonin's anti-inflammatory actions: recent insights and new perspectives. J, Pineal Res (2013) 54:1-14. doi:10.1111/j.1600-079X. 2012.01014.x

182. Srinivasan V, Ohta Y, Espino J, Pariente JA, Rodriguez AB, Mohamed M, et al. Metabolic syndrome, its pathophysiology and the role of melatonin. Recent Pat Endocr Metab Immune Drug Discov (2013) 7:11-25. doi:10.2174/ 1872214811307010011

183. Jiménez-Aranda A, Fernández-Vázquez G, Campos D, Tassi M, Velasco-Perez L, Tan DX, et al. Melatonin induces browning of inguinal white adipose tissue in Zucker diabetic fatty rats. J Pineal Res (2013) 55:416-23. doi:10.1111/jpi.12089

184. Tan DX, Manchester LC, Fuentes-Broto L, Paredes SD, Reiter RJ. Significance and application of melatonin in the regulation of brown adipose tissue metabolism: relation to human obesity. Obes Rev (2011) 12:167-88 doi:10.1111/j.1467-789X.2010.00756.x

185. Lamont KT, Somers S, Lacerda L, Opie LH, Lecour S. Is red wine a SAFE sip away from cardioprotection? Mechanisms involved in resveratrol- and melatonininduced cardioprotection. J Pineal Res (2011) 50:374-80. doi:10.1111/j.1600079X.2010.00853.x

186. Koziróg M, Poliwczak AR, Duchnowicz P, Koter-Michalak M, Sikora J, Broncel M. Melatonin treatment improves blood pressure, lipid profile, and parameters of oxidative stress in patients with metabolic syndrome. J Pineal Res (2011) 50:261-6. doi:10.1111/j.1600-079X.2010.00835.x

187. Reiter RJ, Tan DX, Korkmaz A, Ma S. Obesity and metabolic syndrome: association with chronodisruption, sleep deprivation, and melatonin suppression. Ann Med (2012) 44:564-77. doi:10.3109/07853890.2011.586365

188. Cipolla-Neto J, Amaral FG, Afeche SC, Tan DX, Reiter RJ. Melatonin, energy metabolism, and obesity: a review. J Pineal Res (2014) 56:371-81. doi:10.1111/ jpi.12137 
189. Wu S, Liao AP, Xia Y, Li YC, Li JD, Sartor RB, et al. Vitamin D receptor negatively regulates bacterial-stimulated NF-kappaB activity in intestine. Am J Pathol (2010) 177:686-97. doi:10.2353/ajpath.2010.090998

190. Black PN, Scragg R. Relationship between serum 25-hydroxyvitamin d and pulmonary function in the third national health and nutrition examination survey. Chest (2005) 128:3792-8. doi:10.1378/chest.128.6.3792

191. Kumar J, Muntner P, Kaskel FJ, Hailpern SM, Melamed ML. Prevalence and associations of 25-hydroxyvitamin D deficiency in US children: NHANES 2001-2004. Pediatrics (2009) 124:e362-70. doi:10.1542/peds.20090051

192. Parikh SJ, Edelman M, Uwaifo GI, Freedman RJ, Semega-Janneh M, Reynolds J, et al. The relationship between obesity and serum 1,25-dihydroxy vitamin D concentrations in healthy adults. J Clin Endocrinol Metab (2004) 89:1196-9. doi:10.1210/jc.2003-031398

193. McLachlan CR, Poulton R, Car G, Cowan J, Filsell S, Greene JM, et al. Adiposity, asthma, and airway inflammation. J Allergy Clin Immunol (2007) 119:634-9. doi:10.1016/j.jaci.2006.10.029

194. Roberfroid M, Gibson GR, Hoyles L, McCartney AL, Rastall R, Rowland I, et al. Prebiotic effects: metabolic and health benefits. Br J Nutr (2010) 104:S1-63. doi:10.1017/S0007114510003363

195. Hume ME. Historic perspective: prebiotics, probiotics, and other alternatives to antibiotics. Poult Sci (2011) 90:2663-9. doi:10.3382/ps.2010-01030

196. Magrone T, Perez de Heredia F, Jirillo E, Morabito G, Marcos A, Serafini M. Functional foods and nutraceuticals as therapeutic tools for the treatment of diet-related diseases. Can J Physiol Pharmacol (2013) 91:387-96. doi:10.1139/cjpp-2012-0307

197. Peluso I, Raguzzini A, Villano DV, Cesqui E, Toti E, Catasta G, et al. High fat meal increase of IL-17 is prevented by ingestion of fruit juice drink in healthy overweight subjects. Curr Pharm Des (2012) 18:85-90. doi:10.2174/ 138161212798919020

198. Eckburg PB, Bik EM, Bernstein CN, Purdom E, Dethlefsen L, Sargent M, et al. Diversity of the human intestinal microbial flora. Science (2005) 308:1635-8. doi:10.1126/science.1110591

199. Califf K, Gonzalez A, Knight R, Caporaso JG. The human microbiome: getting personal. Microbe (2014) 9:410-5.

200. Casas R, Sacanella E, Urpí-Sardà M. The effects of the Mediterranean diet on biomarkers of vascular wall inflammation and plaque vulnerability in subjects with high risk for cardiovascular disease. A randomized trial. PLoS One (2014) 9:e100084. doi:10.1371/journal.pone.0100084

Conflict of Interest Statement: The authors declare that the research was conducted in the absence of any commercial or financial relationships that could be construed as a potential conflict of interest.

Received: 07 January 2015; paper pending published: 21 January 2015; accepted: 09 February 2015; published online: 24 February 2015.

Citation: Magrone T and Jirillo E (2015) Childhood obesity: immune response and nutritional approaches. Front. Immunol. 6:76. doi: 10.3389/fimmu.2015.00076

This article was submitted to Nutritional Immunology, a section of the journal Frontiers in Immunology.

Copyright $(\odot) 2015$ Magrone and Jirillo. This is an open-access article distributed under the terms of the Creative Commons Attribution License (CC BY). The use, distribution or reproduction in other forums is permitted, provided the original author(s) or licensor are credited and that the original publication in this journal is cited, in accordance with accepted academic practice. No use, distribution or reproduction is permitted which does not comply with these terms. 